\title{
PENGARUH PRESTASI BELAJAR DAN MOTIVASI BERPRESTA- SI TERHADAP KESIAPAN BERWIRAUSAHA PADA SISWA SMK NEGERI 1 CERME GRESIK
}

\author{
Ellya Fauzia*
}

\begin{abstract}
The objective of this study is to investigate the effect of academic achievement on the entrepreneurship readiness, achievement motivation on the entrepreneurship readiness and both academic achievement and achievement motivation on the entrepreneurship readiness. The population covers 515 students coming from 6 different classes. The samples are 87 students taken from 2 classes of Grade XII Multimedia department and 1 class of Industrial Chemistry. Data were collected using questionnaire. Regression analysis of F-test and t-test were employed to analyze the data. The finding indicates that operational $t$ coefficient of the academic achievement is 4.093 (d.f.: 0.000) and the achievement motivation is 2.350 (d.f.: 0.000). In addition, the operational $F$ coefficient of both academic achievement and achievement motivation is 12.456 (d.f.: 0.000). In conclusion, academic achievement positively influences student's entrepreneurship readiness and so does achievement motivation. Accordingly, both variables influence the students'entrepreneurship readiness.
\end{abstract}

Keywords : academic achievement, achievement motivation, entrepreneurship readiness

\section{PENDAHULUAN}

MK sebagai bentuk satuan penyelenggara dari pendidikan menengah kejuruan yang berada di bawah Direktorat Pembinaan Sekolah Kejuruan, merupakan lembaga pendidikan yang berorientasi pada pembentukan kecakapan hidup, yaitu melatih peserta didik untuk menguasai keterampilan yang dibutuhkan oleh dunia kerja (termasuk dunia bisnis dan industri), memberikan pendidikan tentang kewirausahaan, serta membentuk kecakapan hidup (life skill). Murid di SMK lebih ditekankan untuk melakukan praktik sehingga mereka berpengalaman dan mantap untuk langsung memasuki dunia kerja, tetapi ini tidak menutup kemungkinan para lulusan SMK untuk dapat melanjutkan ke jenjang pendidikan yang lebih tinggi. Selain itu menurut Soenarto (2007:6) "Pendidikan Menengah Kejuruan adalah untuk mempersiapkan peserta didik dengan memberikan bekal keahlian pada bidang spesialisasi khususnya untuk bekerja terjun dimasyarakat, industri dan perdagangan baik dalam bidang produksi maupun pelayanan jasa".

Sekolah Menengah Kejuruan (SMK) didirikan untuk menciptakan sumber daya manusia yang siap bekerja serta mampu menciptakan pekerjaan sesuai dengan keterampilan dan bakat yang dimilikinya. Namun fenomena yang terjadi di lapangan menunjukkan banyak siswa yang belum siap untuk berwirausaha, sebagian yang lain memilih bekerja

*) Guru SMKN 1 Cerme Gresik 
dengan orang lain dan hanya sedikit yang memutuskan membuka usaha sendiri (Tony Wijaya dalam Hartini 2002).

Mengingat tidak semua tenaga pengajar kewirausahaan SMKN 1 Cerme Gresik mempunyai tempat usaha, maka tidak semua tenaga pengajar bisa memberikan keyakinan ke anak didiknya untuk memberikan pengalaman dan keahlian berwirausaha. Prosser dan Snedden dalam Soenarto (2007:29) mengatakan "pendidikan kejuruan akan efektif jika gurunya telah mempunyai pengalaman yang sukses dalam menerapkan pengetahuan dan keterampilan kerja".Dari pernyataan tersebut dapat diartikan bahwa guru pengajar harus mempunyai pengalaman dan keahlian dalam bidangnya karena guru sebagai aktor sebagai variabel penentu keberhasilan pendidikan kejuruan dalam memenuhi misinya menghasilkan lulusan yang memiliki pengetahuan, keterampilan, nilai, sikap dan wawasan untuk masuk ke dunia kerja.

Suatu analisa mengenai faktor-faktor yang mempengaruhi kesiapan siswa untuk berwirausaha, dengan harapan nantinya akan dapat digunakan sebagai pertimbangan guruguru dan sekolah dalam mengembangkan kegiatan pembelajaran kewirausahaan, faktorfaktor tersebut diantaranya adalah prestasi belajar dan motivasi berprestasi.

Prestasi belajar merupakan hasil yang dicapai seseorang setelah melalui proses belajar. Prestasi belajar merupakan suatu hal yang penting dalam kehidupan manusia. Adapun menurut Tu'u (2004:75) Prestasi merupakan hasil yang dicapai seseorang ketika mengerjakan tugas atau kegiatan tertentu. Sementara prestasi belajar adalah penguasaan pengetahuan atau keterampilan yang dikembangkan oleh mata pelajaran, lazimnya ditunjukkan dengan nilai tes atau angka nilai yang diberikan oleh guru.

Prestasi yang diperoleh seseorang banyak dipengaruhi oleh faktor-faktor baik yang berasal dari dalam diri seseorang maupun dari luar diri orang tersebut. Menurut Arikunto (1990:21), secara garis besar faktor-faktor yang mempengaruhi hasil belajar dapat dibedakan menjadi dua jenis yaitu:

- Faktor-faktor yang bersumber dari dalam diri manusia, yaitu faktor biologis dan faktor psikologis. Faktor biologis terdiri dari usia, kematangan dan kesehatan. Sedangkan yang termasuk dalam faktor psikologis adalah kelelahan, suasana hati, motivasi, minat dan kebiasaan belajar.

- Faktor-faktor yang bersumber dari luar diri manusia, yaitu faktor manusia (human) dan faktor non manusia. Faktor manusia dapat berasaldari lingkungan keluarga, sekolah dan masyarakat. Sedangkan faktor non manusia dapat berupa benda, hewan dan lingkungan fisik.

Kurikulum SMK, (2004:10) menuliskan "kewirausahaan adalah salah satu program adaptif yang diajarkan pada siswa SMK selain matematika, bahasa Inggris, bahasa Indonesia, IPA, IPS dan ketrampilan komputer".

Adapun Suryana (2003:8) memberikan batasan bahwa: Ilmu kewirausahaan adalah suatu disiplin ilmu yang mempelajari tentang nilai, kemampuan dan perilaku seseorang dalam menghadapi tantangan hidup untuk memperoleh peluang dengan berbagai resiko yang mungkin dihadapinya.

Motivasi berpangkal dari kata motif yang dapat diartikan sebagai daya penggerak yang ada didalam diri seseorang untuk melakukan aktivitas-aktivitas tertentu demi tercapainya suatu tujuan. Gerungan (1991:140) menambahkan bahwa "motivasi adalah penggerak, alasan-alasan, atau dorongan dalam diri manusia yang menyebabkan dirinya 
melakukan suatu tindakan/bertingkah laku".

Pada dasarnya motivasi seseorang ditentukan oleh tiga kebutuhan, yaitu need for power (kebutuhan akan kekuasaan), need for affiliation (kebutuhan akan afiliasi) dan need for achievement (kebutuhan akan keberhasilan) (McClelland dalam Alma, 2009:96). Teori ini berusaha menjelaskan tingkah laku yang berorientasi pada prestasi yang didefinisikan sebagai tingkah laku yang diarahkan terhadap tercapainya standart of excellent. Penjabaran dari teori kebutuhan yaitu :

1. Need for power (n'Pow): The need to make the other behave in a way that they would not have behaved otherwise.

2. Need for affiliation (n'Aff): The desire for friendly and close interpersonal relationship.

3. Need for achievement (n'Ach): The drive to excel, to achieve in relation to a set of standart, to strive to succed. (McClelland dalam Suryana, 2003:53)

Menurut Martin Handoko seperti yang dikutip oleh TIM MKDK IKIP Surabaya (1995:87), sifat-sifat motivasi terdiri atas:

- Motivasi instrinsik, yaitu motivasi yang berfungsinya tidak usah dirangsang dari luar, karena memang dalam diri individu tersebut sudah ada dorongan untuk melakukan tindakan.

- Motivasi ekstrinsik, yaitu motivasi yang berfungsinya karena disebabkan oleh adanya faktor pendorong dari luar diri individu.

Herminanto Sofyan (1992:10) menyatakan bahwa kesiapan kerja adalah suatu kemampuan seseorang untuk menyelesaikan suatu pekerjaan sesuai dengan ketentuan, tanpa mengalami kesulitan, hambatan dengan hasil maksimal dengan target yang telah ditentukan.

Beberapa prinsip kesiapan adalah:

- Semua aspek perkembangan ini berinteraksi (saling mempengaruhi)

- Kematangan jasmani dan rohani adalah perlu untuk memperoleh manfaat dari pengalaman

- Pengalaman-pengalaman mempunyai pengaruh positif terhadap kesiapan

- Kesiapan dasar untuk kegiatan tertentu terbentuk dalam periode tertentu selama masa pembentukan dan masa perkembangan. (Slameto, 1995:177)

Adapun faktor-faktor yang mempengaruhi kesiapan yaitu:

- Faktor internal, merupakan pengaruh yang berasal dari dalam individu itu sendiri, seperti: kematangan, kecerdasan, keterampilan, kemampuan serta minat, dan motivasi.

- Faktor eksternal, merupakan pengaruh yang berasal dari luar, seperti faktor dari dalam lingkungan sekolah maupun luar sekolah, dan faktor instruksional (kurikulum, bahan pembelajaran, dan metode pembelajaran). (Slameto, 1995)

Nurmiyati (2002:98) menyatakan bahwa seorang siswa yang telah memiliki pengetahuan cenderung ingin mengaplikasikan apa yang telah ia ketahui. Pengetahuan tersebut adalah tentang kewirausahaan, sehingga ia ingin menerapkan pengetahuannya dengan terjun ke dunia usaha dan salah satunya adalah dengan berwirausaha sendiri.

Beberapa penelitian terdahulu yang dikaji ulang:

1. Menurut penelitian Mubadi dan Saptono (2005), menyatakan selain faktor latar belakang siswa berpengaruh pada jiwa kewirausahaan siswa ada faktor lain seperti kualitas program pendidikan siswa. 
2. Menurut penelitian Cokorda (2004), menyatakan pengetahuan kewirausahaan, pengalaman kerja lapangan, persepsi kerja dan sarana pembelajaran praktik merupakan faktor yang berpengaruh dalam kesiapan kerja.

3. Menurut penelitian dari Siti Nurbaya dan Moerdiyanto (2010) menyatakan motivasi berprestasi berpengaruh signifikan terhadap kesiapan berwirausaha serta bahwa pengetahuan kewirausahaan memberikan kontribusi signifikan terhadap kesiapan berwirausaha.

Berdasarkan kajian pustaka diatas, penelti merumuskan hipotesis sebagai berikut:

1. Diduga prestasi belajar berpengaruh signifikan terhadap kesiapan berwirausaha pada siswa SMK Negeri 1 Cerme Gresik.

2. Diduga motivasi berprestasi berpengaruh signifikan terhadap kesiapan berwirausaha pada siswa SMK Negeri 1 Cerme Gresik.

3. Diduga prestasi belajar dan motivasi berprestasi secara bersama-sama berpengaruh signifikan terhadap kesiapan berwirausaha pada siswa SMK Negeri 1 Cerme Gresik.

\section{METODE PENELITIAN}

Metode yang digunakan dalam penelitian ini adalah metode deskriptif kuantitatif. Dengan pendekatan deskriptif, dimana penelitian deskriptif adalah pendekatan yang digunakan untuk menganalisis peristiwa-peristiwa yang terjadi pada saat penelitian berlangsung. Variabel yang digunakan pada penelitian ini adalah Prestasi Belajar (X1), Motivasi berprestasi (X2) dan Kesiapan Berwirausaha (Y).

Populasi dalam penelitian ini seluruh siswa kelas XII SMK Negeri1 Cerme Gresik yang terdiri atas 512 orang siswa. Banyak sampel adalah 87 dari 512 populasi. Lokasi penelitian adalah SMK Negeri 1 Cerme Gresik, Jl. Jurit No.1 Cerme, Gresik.

Model pengukuran yang digunakan untuk menjaring data pada variabel-variabel penelitian ini adalah:

a. Variabel motivasi berprestasi: menggunakan angket/ lembar evaluasi.

b. Variabel kesiapan siswa berwirausaha: menggunakan angket/ lembar evaluasi.

Tes Tulis yang digunakan berupa serangkaian pertanyaan dengan opsi jawaban yang sudah tersedia demi untuk mengukur pengetahuan, inteligensia, kemampuan, bakat yang dimiliki siswa.

\section{HASIL PENELITIAN DAN PEMBAHASAN}

\section{Hasil Penelitian}

\section{Uji Normalitas}

Uji normalitas bertujuan untuk mengetahui apakah dalam suatu model regresi, variabel dependen, independen atau keduanya memiliki distribusi normal atau tidak. Dari gambar grafik diatas dapat dilihat titik-titik menyebar di sekitar garis diagonal serta penyebarannya mengikuti arah garis diagonal, maka model regresi memenuhi asumsi normalitas dan tidak perlu dilakukan pengujian dengan metode statistik non-parametrik karena data sudah berdistribusi normal. 


\section{Normal P-P Plot of Regression Standardized}

Residual

\section{Dependent Variable: VAROOOO3}

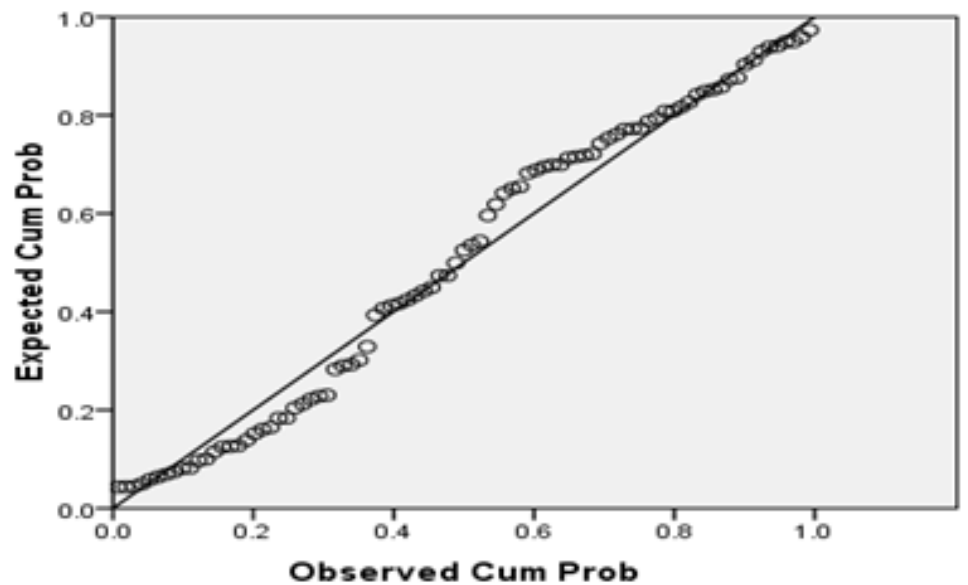

Gambar 1: Uji normalitas dengan diagram P-P plot

\section{Uji Multikolinieritas}

Hasil penghitungan nilai tolerance menggunakan SPSS 20.0 for windows menunjukkan variabel bebas memiliki nilai tolerance mendekati 1 dan lebih dari 0 yang berarti tidak ada korelasi antar variabel bebas Hasil perhitungan nilai Variance Inflation Faktor (VIF) juga menunjukkan hal yang sama yaitu tidak ada variabel bebas yang memiliki VIF lebih dari 10. Dengan demikian dapat disimpulkan bahwa tidak ada multikolinieritas antar variabel bebas dalam model regresi.

3.Uji Heteroskedastisitas

Uji heteroskedastisitas bertujuan untuk menguji apakah dalam model regresi terjadi ketidaksamaan varian residual antara yang satu dengan yang lain.

Scatterplot

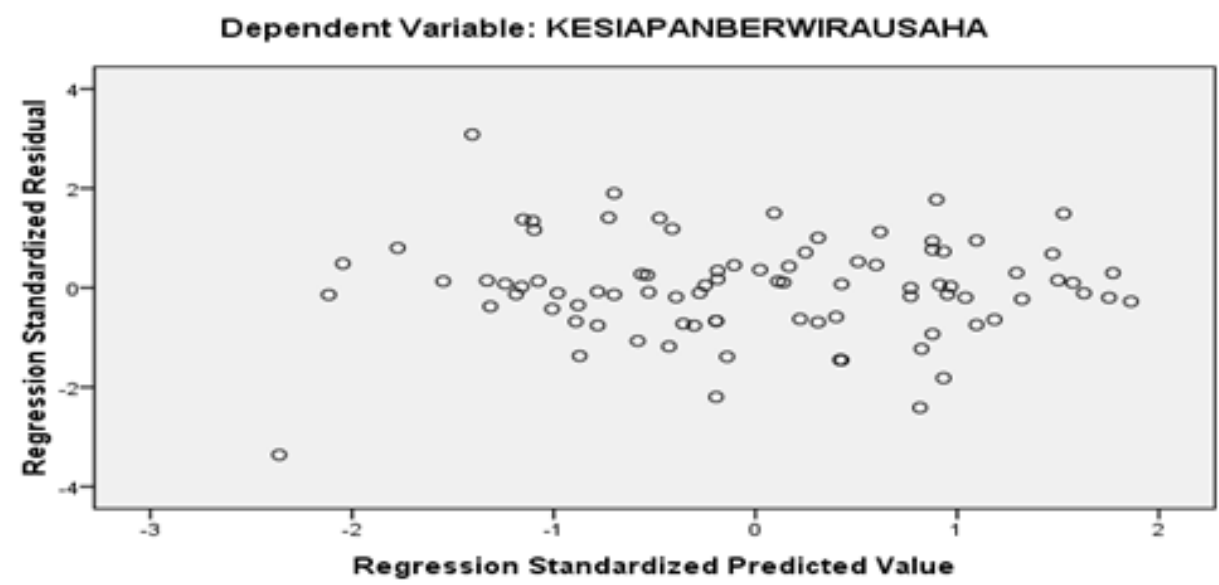

Gambar 2: Uji Heteroskedastisitas 
Pada gambar grafik diatas menunjukkan tidak ada pola yang jelas serta titik-titik menyebar diatas dan di bawah angka 0 pada sumbu Y maka tidak heteroskedastisitas.

4. Uji linieritas

Uji linieritas ini bertujuan untuk mengetahui apakah sebaran data yang diuji mempunyai sebaran yang sesuai dengan garis linier.

Dari hasil penghitungan didapat nilai Prob.F Statistic sebesar 0,6321 $>\alpha(0,5)$, maka model memenuhi asumsi linearitas dan semua nilai Prob.t Stat $>\alpha$, maka variabel independen cocok dimasukkan dalam model Linier. Jadi dapat disimpulkan bahwa data memenuhi asumsi linearitas dan variabel independen cocok dimasukkan dalam model Linier.

Berdasarkan hasil penelitian perhitungan persamaan regresi didapat hasil sebagai berikut : $\mathrm{Y}=13,708+0,304 \mathrm{X} 1+0,135 \mathrm{X} 2+\mathrm{e}$

Hasil persamaam analisis regresi linear berganda diatas mempunyai arti :

a. Konstanta sebesar 13,708 menyatakan jika tidak ada variabel Prestasi Belajar (X1) dan Motivasi Berprestasi(X2), maka Kesiapan Berwirausaha siswa (X3) yang akan diperoleh adalah sebesar 13,7.

b. Koefisien regresi Prestasi Belajar (X1) sebesar 0,304 artinya jika variabel Prestasi Belajar (X1) mengalami peningkatan sebesar 1 satuan sementara variabel Motivasi Berprestasi(X2) tetap, maka akan menyebabkan peningkatan Kesiapan Berwirausaha siswa (X3) sebesar 0,304.

c. Koefisien regresi Motivasi Berprestasi(X2) sebesar 0,135 artinya jika variabel Motivasi Berprestasi(X2) mengalami peningkatan sebesar 1 satuan sementara Prestasi Belajar (X1) tetap maka akan menyebabkan peningkatan Kesiapan Berwirausaha siswa (X3) sebesar 0,135.

Dengan demikian dapat disimpulkan bahwa kedua variabel bebas memiliki koefisien regresi dengan arah positif. Hal ini berarti bahwa peningkatan prestasi belajar dan motivasi berprestasi akan meningkatkan kesiapan berwirausaha dalam diri siswa. Hasil uji $\mathrm{F}$ dari uji ANOVA atau uji statistik $\mathrm{F}$ didapat nilai $\mathrm{F}$ sebesar 12,456 dengan probabilitas 0,000. Nilai signifikansi didapat lebih kecil dari 0,05. maka dari kedua variabel independen Prestasi belajar maupun motivasi berprestasi secara bersama-sama berpengaruh signifikan terhadap Kesiapan berwirausaha siswa SMKN 1 Cerme Gresik.

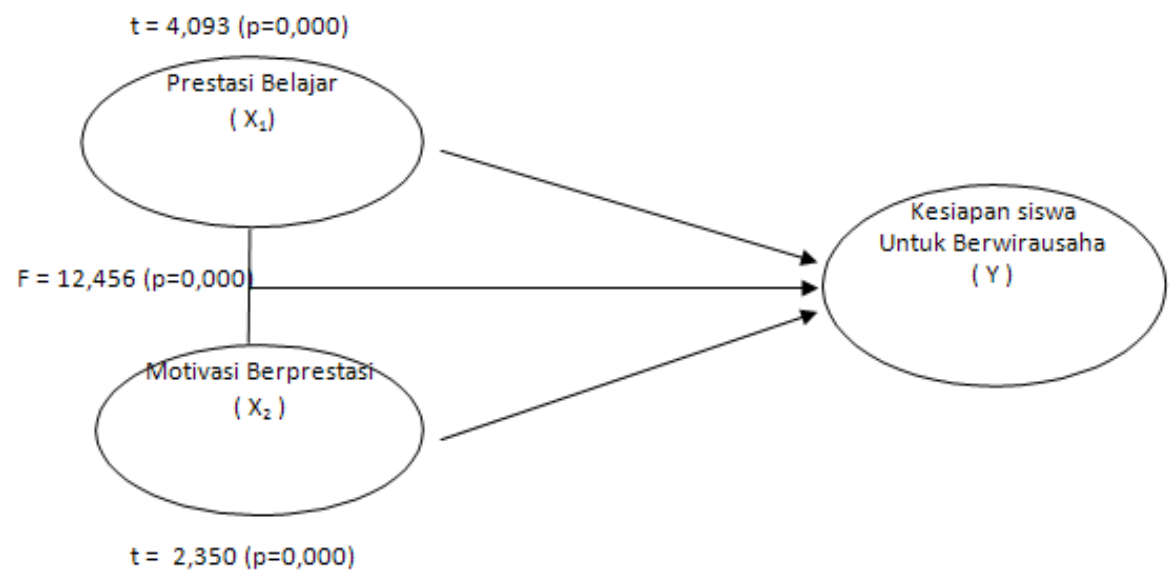

Gambar 3. Hasil uji hipotesis 
Berdasarkan hasil perhitungan regresi diketahui bahwa determinasi (adjusted R2) yang diperoleh sebesar 0,208. Hal ini menunjukkan 20,8\%\% variabel terikat kesiapan berwirausaha dipengaruhi oleh variabel bebas yaitu prestasi belajar dan motivasi berprestasi.

Dari hasil uji parsial didapatkan variabel prestasi belajar memiliki t hitung sebesar 4,093 dengan signifikansi 0,000; variabel motivasi berprestasi memiliki t hitung sebesar 2,350 dan signifikansi 0,021. semua nilai signifikasi dari masing-masing variabel independen baik Prestasi belajar yaitu 0,000 maupun motivasi berprestasi yaitu 0,021 lebih kecil dari alpha $(0,05)$, maka semua variabel dependen berpengaruh secara parsial terhadap Kesiapan berwirausaha siswa SMKN 1 Cerme Gresik.

\section{Pembahasan}

Berdasarkan hasil pengujian hipotesis disimpulkan bahwa semua hipotesis diterima. Variabel motivasi berprestasi dan prestasi belajar terbukti signifikan baik secara parsial maupun secara simultan (bersama-sama) mempengaruhi kesiapan berwirausaha.

1. Prestasi Belajar Berpengaruh Signififikan terhadap Kesiapan Berwirausaha

Berdasarkan analisis data diperoleh hasil yang menunjukkan bahwa prestasi belajar memiliki pengaruh signifikan terhadap kesiapan berwirausaha pada siswa. Besarnya pengaruh prestasi belajar akan meningkatkan kesiapan berwirausaha pada diri siswa.

Hasil pengujian ini mendukung teori Ibnoe Soedjono dan Ropke yang dikutip oleh Suryana (2003:39), Casson (1982), A.Kuriloff, dkk(1993:8) dan Carol Noore (dalam Suryana, 2003:40). Hasil penelitian ini juga sesuai dengan hasil penelitian terdahulu yang dilakukan oleh Mubadi dan Saptono (2005), Cynthia dan Sularto (2011) serta Aditya Indra Putra, dkk (2009) yang menyimpulkan bahwa "Prestasi belajar berpengaruh signifikan terhadap kesiapan berwirausaha". Juga yang telah disampaikan dalam penelitian oleh Prince Famous Izedonmi dan Chinonye Oka (2010) yang menyimpulkan bahwa "The analysis result shows that knowledge and skills is/are major influencing factor(s) in the students entrepreneurial intentions".

Menurut Ibnoe Soedjono dan Ropke yang dikutip oleh Suryana (2003:39) menyatakan bahwa: "Perilaku kewirausahaan dipengaruhi oleh faktor internal dan eksternal. Faktor-faktor itu adalah hak kepemilikan, kemampuan/kompetensi dan insentif, sedangkan faktor eksternalnya meliputi lingkungan. Senada dengan apa yang telah disampaikan oleh Carol Noore dalam Suryana (2003:40) proses kewirausahaan diawali dengan inovasi. Inovasi tersebut dipengaruhi oleh berbagai faktor baik internal maupun eksternal seperti pendidikan, sosiologi, organisasi, kebudayaan dan lingkungan.

Terdapat berbagai kemampuan/kompetensi yang harus dimiliki seorang wirausahawan seperti yang dikemukakan oleh Casson (1982) "Ada beberapa kemampuan yang harus dimiliki, yaitu: knowledge, imagination and skill”. Didukung juga oleh A.Kuriloff, dkk (1993:8) ada empat kemampuan utama yang diperlukan untuk mencapai pengalaman yang seimbang agar kewirausahaan berhasil, diantaranya: Technical competence, marketing competence, financial competence dan human relation competence.

Dalam penelitian ini prestasi belajar mencerminkan kemampuan siswa dalam penguasaan materi kewirausahaan secara menyeluruh, instrumen tes yang telah disusun meliputi semua kompetensi kewirausahaan yang ada di SMK. Selain mencerminkan kemampuan penguasaan materi, prestasi belajar disini juga mencerminkan kemampuan dan antusiasme siswa dalam kegiatan praktik kewirausahaan yang meliputi kegiatan survey pasar, penggalian potensi diri berdasarkan kemampuan dan kelayakan produk serta 
pemasaran produk. Sehingga hasil dari analisa data memberikan informasi yang akurat, bahwasannya prestasi belajar siswa merupakan salah satu faktor yang dapat membentuk minat siswa untuk berwirausaha.

Implikasi lain dari hasil penelitian ini adalah dalam rangka menumbuhkan minat siswa untuk berwirausaha diperlukan beberapa tahapan yang tidak dapat ditinggalkan adalah tatanan pendidikan yang diterima oleh siswa. Dalam melaksanakan proses pembelajaran siswa akan mendapatkan pengetahuan, pengalaman dan keterampilan yang nantinya akan sangat berpengaruh pada saat mereka terjun di masyarakat. Pengetahuan, pengalaman dan keterampilan yang diperoleh siswa merupakan modal dasar yang dapat digunakan selain untuk bekerja juga untuk berwirausaha, setelah lulus sekolah nantinya. Oleh karena itu hipotesis yang menyatakan "Diduga prestasi belajar berpengaruh signifikan terhadap kesiapan berwirausaha" dapat diterima.

2. Motivasi Berprestasi Berpengaruh Signifikan terhadap Kesiapan Berwirausaha

Berdasarkan analsis data diperoleh hasil bahwa motivasi berprestasi memiliki pengaruh yang signifikan terhadap kesiapan berwirausaha pada siswa. Motivasi berprestasi yang lebih besar pada diri siswa akan dapat lebih meningkatkan kesiapan berwirausaha dalam diri siswa tersebut.

Hasil pengujian hipotesis ini mendukung teori yang disampaikan oleh Mc Clelland (dalam Suryana 2003: 39) dan Meredith (2000:5). Demikian juga sesuai dengan penelitian terdahulu yang dilakukan oleh Tony Wijaya (2008), Wahid munawar (2009), Muladi Wibowo (2011), Anis Syarifudin Adi (2011), serta Siti Nurbaya dan Moerdiyanto (2012) yang menyimplkan bahwa "Motivasi berprestasi berpengaruh signifikan terhadap kesiapan berwirausaha".

Menurut David Mc Clelland seperti yang dikutip oleh Suryana (2003:39) mengemukakan: Kewirausahaan ditentukan oleh motif berprestasi, optimisme, sikap-sikap nilai dan status kewirausahaan". Hubungan positif antara motivasi berprestasi dan kesiapan berwirausaha menjelaskan seberapa kuat motivasi yang dimiliki individu akan banyak menentukan terhadap kualitas perilaku yang ditampilkannya, baik dalam konteks belajar, bekerja maupun dalam kehidupan lainnya. Apabila seseorang mempunyai minat yang tinggi terhadap sesuatu hal maka akan terus berusaha untuk melakukan sehingga apa yang diinginkannya dapat tercapai sesuai dengan keinginannya. Hal tersebut sesuai juga dengan yang telah disampaikan oleh Meredith (2000:5) bahwa seorang wirausahawan adalah individu-individu yang berorientasi kepada tindakan dan bermotivasi tinggi yang berani mengambil resiko dalam mengejar tujuan.

Motivasi dalam berwirausaha adalah faktor yang penting karena hal tersebut merupakan keadaan yang mendorong semangat berwirausaha, motivasi dapat memberi semangat terhadap peserta didik/warga belajar dalam mengikuti kegiatan pembelajaran yang dilaksanakan. Sedangkan semangat wirausaha adalah merupakan jiwa wirausaha yang merupakan kekuatan dalam menjalankan wirausaha agar kegiatan wirausaha sukses sesuai dengan visi yang ditetapkan. Oleh karena itu perlu adanya motivasi, kreativitas dan inovasi agar seseorang memiliki semangat cukup kuat untuk berwirausaha. Semakin kuat motivasi seseorang maka semakin kuat pula untuk melakukan ide dan hal ini dapat dikatakan sebagai semangat melakukan tindakan. Untuk menumbuhkan motivasi diri, "pemicunya" adalah visualisasi akan bisnis masa depan, tanggung jawab akan pelaksanaan bisnis yang dijalani, kondisi usaha terasa nyaman dan disukai, rajin dan ulet dalam menjalaninya. Hal tersebut sesuai dengan yang telah disampaikan oleh Rusyam (1989:99) yang mengatakan 
bahwa: "Motivasi merupakan penggerak tingkah laku kearah suatu tujuan dengan didasari oleh adanya suatu keinginan/kebutuhan". Serta Wahjosumidjo (1987:174) yang memberikan suatu definisi: "Motivasi adalah suatu proses psikologi yang mencerminkan interaksi antara sikap, kebutuhan, persepsi dan keputusan yang terjadi pada diri seseorang untuk bertingkah laku dalam rangka memenuhi kebutuhan yang dirasakan."

Keahlian dimiliki oleh siswa sesuai dengan jurusan masing-masing. Dua hal diatas menunjukkan bahwa masih terdapat keinginan atau motivasi siswa untuk berprestasi.

Secara cepat, tidak memandang suatu masalah dari satu sisi saja. Kemampuan seperti ini sangat diperlukan dalam berwirausaha. Dia tidak takut dalam menghadapi resikoresiko yang ada dalam permasalahan.

Dengan demikian, berbagai upaya peningkatan motivasi berprestasi yang dilakukan oleh siswa dapat meningkatkan kesiapan siswa untuk berwirausaha. Implikasi lain dari hasil penelitian ini bahwa siswa memiliki tanggung jawab, orientasi sukses dan tangguh dalam mencapai tujuan yang diharapkan untuk masa depan mereka. Oleh karena itu hipotesis yang menyatakan "Diduga motivasi berprestasi berpengaruh signifikan terhadap kesiapan berwirausaha" dapat diterima.

3. Diduga Prestasi Belajar dan Motivasi Berprestasi Secara Bersama-sama Berpengaruh Signifikan terhadap Kesiapan Berwirausaha

Berdasarkan analsis data diperoleh hasil bahwa prestasi belajar dan motivasi berprestasi secara bersama-sama berpengaruh signifikan terhadap kesiapan berwirausaha pada siswa. Hal ini menunjukkan bahwa semakin positif baik prestasi belajar maupun motivasi berprestasi, maka semakin tinggi pula kesiapan berwirausaha. Sebaliknya semakin negatif prestasi belajar ataupun motivasi berprestasi maka semakin rendah pula kesiapan berwirausaha.

Kecilnya pengaruh variabel bebas yaitu prestasi belajar dan motivasi berprestasi, yang hanya sebesar $20,8 \%$ terhadap kesiapan berwirausaha dapat dijelaskan bahwasannya variabel lain mempunyai pengaruh lebih besar terhadap kesiapan berwirausaha di SMK Negeri 1 Cerme Gresik. Sesuai dengan yang disampaikan oleh David Mc Clelland yang dikutip oleh Suryana (2003:39) mengemukakan: Kewirausahaan ditentukan oleh motif berprestasi, optimisme, sikap-sikap nilai dan status kewirausahaan". Lebih lanjut apa yang dikemukakan diatas dilengkapi oleh Ibnoe Soedjono dan Ropke yang dikutip oleh Suryana (2003:39) bahwa: "Perilaku kewirausahaan dipengaruhi oleh faktor internal dan eksternal. Faktor-faktor itu adalah hak kepemilikan, kemampuan/kompetensi dan insentif, sedangkan faktor eksternalnya meliputi lingkungan". Teori di atas juga di lengkapi oleh Carol Noore dalam Suryana (2003:40) proses kewirausahaan diawali dengan inovasi. Inovasi tersebut dipengaruhi oleh berbagai faktor baik internal maupun eksternal seperti pendidikan, sosiologi, organisasi, kebudayaan dan lingkungan. Dari berbagai teori di atas dapat dijelaskan bahwasannya kesiapan berwirausaha siswa khususnya di SMK Negeri 1 Cerme Gresik lebih besar (79,2\%) ditentukan oleh variabel-variabel diluar yang penulis teliti. Sehingga diperlukan penelitian lain yang menghubungkan variabel-variabel lain tersebut terhadap kesiapan berwirausaha siswa.

Hasil penelitian terdahulu yang mengemukakan variable-variabel yang mempengaruhi kesiapan berwirausaha juga telah dilakukan diantaranya: Menurut penelitian Cokorda Istri Raka Marsiti tahun 2004, "Pengetahuan kewirausahaan, pengalaman kerja lapangan, persepsi kerja dan sarana pembelajaran praktik merupakan faktor yang berpengaruh dalam kesiapan kerja”. Didukung juga dengan yang telah diteliti oleh Cynthia Agustina 
dan Lana Sularto tahun 2011 tentang intensi kewirausahaan mahasiswa disimpulkan bahwasannya Ada pengaruh yang besar dari kebutuhan akan pencapaian, efikasi diri, kesiapan instrumentasi, pengalaman kerja dan prestasi akademik terhadap intensi kewirausahaan, perbedaan gender tidak berpengaruh pada intensi kewirausahaan. Senada dengan kedua penelitian diatas yaitu yang telah didapatkan oleh Hafiz Ullah, dkk tahun 2011 dalam "The impact of Owner Psychological Factors on Entrepreneurial Orientation: Evidence from Khyber Pakhtunkhwa-Pakistan" diketahui bahwa: "Entrepreneurial oriented members possessed high need for achievement motivation, more internal locus of control, greater tolerance for ambiguity and has more intuition level which plays an important role in entrepreneurial orientation". Hasil dari penelitian-penelitian di atas menambahkan data bahwasannya terdapat berbagai variabel yang dapat menentukan kesiapan siswa berwirausaha. Sehingga kecilnya pengaruh variabel bebas prestasi belajar dan motivasi berprestasi terhadap kesiapan siswa SMK Negeri 1 Cerme Gresik untuk berwirausaha dikarenakan terdapat variabel-variabel lain yang mempunyai pengaruh lebih besar.

Berdasarkan analisa data regresi berganda didapatkan bahwa variabel prestasi belajar mempunyai koefisien kontribusi yang lebih besar $(0,304 \%)$ dibandingkan dengan variabel motivasi berprestasi $(0,135 \%)$. Hal ini didukung dengan hasil pada data komposisi responden bahwasannya prosentase keikutsertaan siswa pada kegiatan-kegiatan yang berhubungan dengan peningkatan prestasi belajar (kegiatan rutin belajar, kegiatan praktek industri dan kegiatan les) lebih tinggi apabila dibandingkan dengan prosentase keikutsertaan siswa pada kegiatan-kegiatan yang berhubungan dengan motivasi (kegiatan lomba, kegiatan dalam organisasi dan kursus keahlian).

Pengaruh kedua variabel tersebut terhadap kesiapan berwirausaha dapat diperjelas dengan data komposisi responden, bahwa dari 87 responden terdapat 34,5\% siswa sudah pernah menjalankan usaha sendiri, sehingga siwa mampu memenuhi kebutuhan 2\% wirausaha sudah berhasil sesuai dengan standar wirausaha di Indonesia, sedang 65,5 \% tidak pernah menjalankan usaha sendiri. Hal di atas dapat dijelaskan bahwasannya responden yang tidak pernah ikut menjalankan usaha sendiri bukan berarti tidak memiliki jiwa/kesiapan untuk berwirausaha, karena faktor-faktor lainlah yang menyebabkan mereka belum mempunyai kesempatan untuk berwirausaha. Memiliki jiwa wirausaha bukan berarti harus memiliki sebuah usaha atau menjalankan praktek kewirausahaan. Mental itu akan selalu melekat pada pribadi masing-masing yang suatu saat selalu siap untuk diaplikasikan manakala situasi, kondisi dan kesempatan berwirausaha itu telah ada. Karena kesadaran bahwa mereka telah memiliki jiwa sebagai wirausaha seperti memiliki kepercayaan diri dalam bertindak, inovatif dan kreatif, kepemimpinan, efektif dan efisien, serta selalu berorientasi pada masa depan dalam merencanakan sesuatu telah ada, maka tinggal meningkatkan dan memunculkan faktor eksternal agar keinginan mereka untuk menjadi wirasahawan segera terwujud.

Tingginya semangat wirausaha dalam jiwa siswa merupakan harapan cerah bagi lembaga untuk membantu program pemerintah dalam mencetak wirausaha-wirausaha mandiri, sehingga jumlah wirausaha di Indonesia akan mencapai standar yaitu sebanyak $2 \%$ dari total penduduk sehingga dapat meningkatkan perekonomian bangsa Indonesia kedepan. Indonesia akan menjadi bangsa yang kuat karena ditopang oleh wirausahawirausaha yang kuat dan handal. Salah satu usaha yang dapat dilakukan adalah dengan meningkatkan kualitas pembelajaran kewirausahaan. Guru sebaiknya memiliki pengalaman yang baik dalam berwirausaha sehingga siswa tidak hanya mendengarkan teori na- 
mun sebuah pengalaman nyata sehingga lebih terserap/mendarah daging dalam jiwa dan akan memupuk keberanian untuk memulai usaha sendiri. Selain itu materi kewirausahaan perlu dikemas semenarik mungkin sehingga tidak monoton, membosankan, karena sangat teoristis. Ditunjang juga dengan menambah frekuensi pelatihan kewirausahaan yang dipadankan dengan potensi keunggulan tiap program keahlian serta satu hal lagi yang belum dilakukan oleh sekolah yaitu memberikan pendampingan kepada siswa yang telah memulai untuk menjalankan usaha sendiri.

Keinginan semua orang untuk terus maju dan berprestasi tidak dapat dihindari. Seseorang memiliki minat berwirausaha karena adanya motif tertentu. Motivasi berprestasi ialah suatu nilai sosial yang menekankan pada hasrat untuk mencapai yang terbaik guna mencapai kepuasan secara pribadi. Seorang wirausaha yang ingin berhasil di dalam usahanya janganlah loyo, pasrah diri, tidak mau berjuang, tetapi harus bersemangat tinggi, berjuang dan berambisi ingin maju dengan komitmen tinggi terhadap pekerjaannya. Dengan berbuat dan bekerja prestatif terhadap bisnisnya, wirausaha tersebut akan berhasil di dalam kegiatan usahanya. Berbuat, belajar dan bekerja secara prestatif merupakan modal dasar untuk keberhasilan seorang wirausaha. Seorang wirausaha yang berhasil selalu menempuh saat-saat di mana ia harus bekerja keras, membanting tulang dalam merintis bisnisnya. Seorang wirausaha yang mempunyai semangat tinggi, mau berjuang untuk kemajuan bisnisnya. Seorang wirausaha yang mempunyai semangat tinggi, mau berjuang untuk maju berbisnis. Ia yang berbuat dan bekerja secara prestatif dan selalu gigih dalam menghadapi pekerjaan serta tantangan yang dihadapinya biasanya selalu berhasil di dalam usahanya. Oleh karena itu hipotesis yang menyatakan "Diduga prestasi belajar dan motivasi berprestasi secara bersama-sama berpengaruh signifikan terhadap kesiapan berwirausaha" dapat diterima.

\section{KESIMPULAN}

Berikut ini akan dipaparkan simpulan berdasarkan pembahasan yang telah diuraikan:

1. Prestasi belajar memiliki pengaruh signifikan terhadap kesiapan berwirausaha. Peningkatan prestasi belajar yang lebih tinggi yang diperoleh siswa dapat meningkatkan kesiapan berwirausaha dalam diri siswa.

2. Motivasi berprestasi memiliki pengaruh signifikan terhadap kesiapan berwirausaha pada siswa. Semakin tinggi motivasi berprestasi pada diri siswa dapat meningkat kesiapan berwirausaha.

3. Prestasi belajar dan motivasi berprestasi secara bersama-sama memiliki pengaruh yang signifikan terhadap kesiapan berwirausaha pada siswa. Semakin tinggi prestasi belajar, semakin besar motivasi berprestasi akan mendorong kesiapan berwirausaha siswa.

Penelitian tentang Pengaruh Prestasi belajar dan Motivasi berprestasi terhadap Kesiapan Berwirausaha pada Siswa SMK Negeri 1 Cerme Gresik mempunyai beberapa keterbatasan, sehingga dapat diajukan beberapa saran sebagai berikut:

1. Berkaitan dengan prestasi belajar yang berpengaruh signifikan terhadap kesiapan berwirausaha, sekolah dapat menambah jam pelajaran kewirausahaan dikelas X SMK Negeri 1 Cerme Gresik, sebab selama ini pada kelas X tidak ada mata pelajaran kewirausahaan sehingga pembelajaran kewirausahaan lebih optimal dalam mendukung faktor kesiapan berwirausaha. 
2. Berkaitan dengan faktor motivasi berprestasi yang berpengaruh signifikan terhadap kesiapan berwirausaha, perlu ditingkatnya motivasi berprestasi melalui pembelajaran kewirausahaan yang tidak hanya memberikan informasi tetapi pembentukan jiwa dan kemampuan membaca peluang usaha, yaitu berupa kisah para wirausahawan yang sukses menekuni usahanya diawali oleh kejelian mereka dalam melihat peluang usaha yang ada. Hal ini agar membangun kepekaan dalam membaca peluang semakin melekat pada diri siswa sehingga akan meningkatkan motivasi berprestasi serta mendorong kesiapan berwirausaha.

3. Berdasarkan hasil perhitungan regresi diketahui bahwa determinasi (adjusted R2) yang diperoleh $20,8 \%$ variabel terikat kesiapan berwirausaha dipengaruhi oleh variabel bebas, sehingga masih terdapat 79,2\% variabel lain yang mempengaruhi siswa untuk meningkatkan kesiapan berwirausaha, hal ini dapat menjadi pertimbangan bagi peneliti yang akan datang agar menambah data variabel lain, seperti variabel peranan orang tua, variabel pengalaman praktek industri, variabel pengetahuan kewirausahaan yang dapat meningkatkan kesiapan berwirausaha.

4. Berdasarkan data komposisi responden tentang kesiapan berwirausaha siswa di SMK Negeri 1 Cerme Gresik menunjukkan hasil yang kurang memuaskan karena 65,5 \% siswa masih belum pernah melakukan usaha sendiri, oleh karena itu perlu adanya kegiatan praktek wirausaha yang memberikan inspirasi pada sistem untuk berwirausaha, disamping itu peranan lembaga sekolah sangat menentukan tercetaknya wirausaha muda yang handal.

\section{DAFTAR RUJUKAN}

Agustina, Cynthia. Lana Sularso. 2011. Intensi Kewirausahaan Siswa. Jurnal Proceeding PESAT, Vol. 4, Oktober 2011.

Alma, Buchari. 2009. Kewirausahaan. Edisi Revisi. Penerbit Alfabeta.

Arikunto, Suharsimi. 1990. Manajemen Pengajaran Secara Manusiawi. Jakarta: PT. Rineka Cipta.

Casson, Mark C. (1982) The Entrepreneur: An Economic Theory, Oxford: Martin Robertson,

Drucker, Peter F. 1999. Management: tasks, responsibilities, practices, Gulf Professional Publishing

Gerungan. 1991. Kamus Bahasa Indonesia Modern. Jakarta : Djambatan

Handoko, Martin. 1992. Motivasi Daya Penggerak Tingkah Laku. Jakarta: Rineka Cipta

Herminanto, Sofyan. 1992. Kesiapan Kerja Siswa STM di Jawa. Laporan Penelitian. Yogyakarta: IKIP Yogyakarta.

Kuriloff, Arthur H., John M. Hemphill, Jr., and Douglas Cloud, 1993, Starting and Managing The Small Business, Third Edition, Mc Graw-Hill, Inc., Singapore.

Marsiti, Cokorda Istri Raka. 2004. Kesiapan Kerja untuk Berwirausaha Siswa SMK Negeri jurusan boga di Propinsi Bali. Jurnal Pendidikan dan Pengajaran IKIP Negeri Singaraja, No.2 TH. XXXVII April 2004. 
McClelland, D.C. 1987. Human Motivation. New York: Cambridge University Press.

Meredith, Geoffrey G. 2000. Kewirausahaan: Teori dan praktek. Jakarta: PT. Pustaka Binaman Pressindo.

Mubadi, F.X., Laurentius Saptono. 2005. Jiwa Kewirausahaan Siswa SMK : Suatu Survey pada 3 SMK Negeri dan 7 SMK Swasta di DIY. Jurnal Widya Dharma, Vol 16, No.1, Oktober 2005

Munawar, Wahid. 2009. Hubungan Motivasi Berprestasi dengan Sikap Siswa SMK terhadap Kewiraswastaan. Jurnal INVOTEC, Volume 15, No.15, Agustus 2009: 444-449.

Nurbaya, Siti., Moerdiyanto. 2010. Faktor - Faktor yang Mempengaruhi Kesiapan Berwirausaha Siswa Kelas XII SMKN Barabai Kabupaten Hulu Sungai Tengah Kalimantan Selatan. Jurnal studies in educational leadership. Vol. 11, 2010.

Putra, Aditya Indra., Sunyoto, Rahmad Doni Widodo. 2009. Pengaruh Pengalaman Praktek Kerja Industri terhadap Minat Berwirausaha pada Siswa kelas XII Program Keahlian Teknik Mekanik Otomotif SMK TEXMACO Pemalang. Jurnal PTM, Vol 9, No.1, Juni 2009.

Rusyam, A.Tabrani. 1989. Motivasi Belajar Warga di PKBM . Bandung : Angkasa

Slameto. 1995. Belajar dan Faktor-faktor yang mempengaruhinya. Jakarta: Rineka Cipta

Suryana. 2003. Kewirausahaan. Jakarta: Salemba Empat.

Tim MKDK IKIP Surabaya.1995. Pengantar Pendidikan : Bagian I. Surabaya: University Press IKIP Surabaya.

Tu'u, Tulus. 2004. Peran Disiplin Pada Perilaku dan Prestasi Siswa. Jakarta: Grasinda

Ullah, Hafiz., Prof. Dr. Bahadar Shah., Faqir Sajjad Ul Hassan, Tariq Zaman. 2011. The Impact of Owner Psycological Factors on Entrepreneurial Orientation: Evidence from Khyber Pakhtunkhwa-Pakistan. International Journal of Educationand Social Sciences (IJESS), Vol. 1, No.1, 2011.

Wahjosumidjo. 1987. Kamus Umum Bahasa Indonesia. Jakarta : Gramedia

Wibowo, Muladi. 2011. Jurnal Eksplanasi Vol. 6 (2)

Wibowo, Muladi. 2011. Pembelajaran Kewirausahaan dan Minat Wirausaha Lulusan SMK. Jurnal Eksplanasi, Vol 6, No.2, September 2011.

Wijaya, Tony. 2008. Kajian Model Empiris Perilaku Berwirausaha UKM DIY dan Jawa Tengah. Jurnal Manajemen dan Kewirausahaan, Vol 10, No.2, September 2008: 93-104. 